\title{
Effects of Spraying Yeast, Algae and Fish Oil on Growth and Fruiting of Ruby Seedless Grapevines
}

\author{
Masoud, A.A.B. and Eman A.A. Abou-Zaid \\ Pomology Dept., Fac. Agric., Assiut University, Assiut, Egypt.
}

Received on: 9/3/2017

Accepted for publication on: 20/3/2017

\section{Abstract}

The experiment was conducted during the two successive seasons of 2015 and 2016 on Ruby Seedless grapevines grown in the Experimental Orchard, Faculty of Agriculture, Assiut University. This investigation was carried out to study the effect of spraying yeast, algae and fish oil on vegetative growth, nutrient status and fruiting. The experiment was set up in a randomized complete block design with three replicates, one vine per each. The obtained results could be summarized as follows:

- Pruning wood weight, leaf area and its nutritional status significantly increased with spraying yeast, algae and fish oil compared to unsprayed ones. Spraying yeast combined with algae plus fish oil at half concentration of single spraying gave the maximum values of these aspects.

- Spraying yeast combined with algae and fish oil gave the highest cluster number, heaviest clusters and yield/vine compared to the other spraying treatments and unsprayed ones. No significant differences were observed among double spraying form or triple ones.

- All yeast, algae or fish oil treatments significantly improved the berry quality in terms of increasing berry weight, total soluble solids $\%$, reducing sugars $\%$ and skin berry anthocyanin and decreasing titratable acidity $\%$ compared to unsprayed ones. The present study concluded that carrying out sprays of mixture of $5 \mathrm{~g} / \mathrm{L}$ yeast, $0.5 \mathrm{~g} / \mathrm{L}$ algae or $0.5 \mathrm{ml} / \mathrm{L}$ fish oil improved the growth and nutritional status of vines, in addition get high yield with good cluster and berry attributes.

Keywords: Yeast, Algae, Fish oil, spraying, Ruby Seedless grapevines.

\section{Introduction}

The grape is considered one of the most important fruits crop in the world. The grapes included more than 60 known species. In Egypt, it is ranked the second fruit crop after citrus, the cultivated area has grown rapidly because of its high return where it reached 19294 fed that yielded 1596169 ton of fruits (M.A.L.R. 2014).

The grape can be used fresh or used for making jam, juice, wine, jelly and extract the grape seed oil extract, nice taste and high nutritional value (Hulme, 1971).

Ruby Seedless is a hybrid of "Emperior" a red seeded Table cv. and "Pirovance 75" a large White Seedless Italian cv. (Olmo et al., 1981).

The grapevines require adequate cultural practices, appropriate climatic and soil conditions. Fertilization, as a cultural practice is one of the important tools to improve the soil fertility and increase crop yield.

Bio-fertilizers are organisms that contain vitamins, minerals and 
other useful compounds. It is used as a promising alternative for chemical fertilizers. It is very useful for human, animals and environment (Suba Rao, 1984; Verna, 1990; Abd El-Hamid, 2002 and El-Salhy et al., 2006). Fresh yeast contains from different nutrient, larger amount of vitamin B and other natural plant growth hormone namely cytokinin. In addition, it releases $\mathrm{CO}_{2}$ which is reflected on improving the net photosynthesis (Ferguson et al., 1987; Idso et al., 1995 and Hashem et al., 2008). Active dry yeast was found to enhance grape yield and physico-chemical characteristics of berries (Ahmed et al., 1997; El-Mogy et al., 1998; Nomier, 2000; Ismaeil et al., 2003; El-Salhy et al., 2006; Mostafa, 2008; El-Salhy et al., 2011 and Masoud, 2012). Seaweed extract being organic and biodegradable in nature and considered as an important source of nutrition for sustainable agriculture (Cassan et al., 1992). Algae extract is one of the most leading biofertilizers, containing $\mathrm{N}, \mathrm{P}, \mathrm{K}, \mathrm{Ca}$ and other minerals, some growth regulators, polyamines and vitamins that may be used to improve nutritional status, vegetative growth, yield and fruit quality (Metting et al., 1990; Abd El-Migeed et al., 2004; Eman,
Abd El-Moniem and Abd-Allah, 2008; Spinelli et al., 2009 and Khan et al., 2012).

The fish oil spraying was found to reduce fruit set, thus it is considered as an efficient bloom thinner in Golden Delicious and Red Chief Delicious apple trees (McArthey et al., 2006 and David et al., 2008). Fish oil is a natural product composed of the fatty acid esters of glycerol as an alternative to synthetic fungicides and insecticides (Osnaya and Schlöser, 1998). Therefore, this study was conducted to declare the effect of yeast, algae and fish oil as a spray on growth and productivity of Ruby Seedless grapevines.

\section{Materials and Methods}

This experiment was carried out during the two seasons 2015 and 2016 on Ruby Seedless grapevines. Vines were 25 years old at the beginning of the experiment, spaced at $2 \times 2.5 \mathrm{~m}$ apart. The vines grown at the experimental orchard of the Faculty of Agriculture, Assiut University, where the soil is clay texture and well drained. Some physical and chemical properties of the soil were analysed according to Wilde et al. (1985) and shown in Table 1.

Table 1. Some physical and chemical properties of experimental orchard soil.

\begin{tabular}{|c|c|c|c|c|c|}
\hline $\begin{array}{c}\text { Soil } \\
\text { property }\end{array}$ & Value & Soil property & Value & Soil property & Value \\
\hline Sand $\%$ & 15.43 & Organic matter \% & 1.32 & $\mathrm{NH}_{4} \mathrm{OAC}$ extractable $\mathrm{K}(\mathrm{ppm})$ & 401.33 \\
\hline Silt \% & 33.22 & $\mathrm{pH}(1: 1$ suspension $)$ & 8.10 & DTPA extractable Fe (ppm) & 13.19 \\
\hline Clay \% & 51.35 & $\operatorname{ECe}\left(\mathrm{dS} / \mathrm{m}^{-1}\right)$ & 2.69 & DTPA extractable Mn (ppm) & 15.16 \\
\hline Texture & Clay & Total N (\%) & 0.16 & DTPA extractable Zn (ppm) & 2.35 \\
\hline $\mathrm{CaCO}_{3} \%$ & 3.66 & $\mathrm{NaHCO}_{3}$-extractable (pm) & 21.61 & DTPA extractable $\mathrm{Cu}(\mathrm{ppm})$ & 2.11 \\
\hline
\end{tabular}

The vines were trained as the bilateral cordon, the trellis system was traditional three wires and pruned during the second week of January. Total bud load of 60 buds/vine (16 fruiting spurs x 3 buds +6 replace- 
ment spurs x 2 buds/vine). The chosen vines were received the same cultural practices including green operations, insecticide and pesticide applications except for the tested different treatments through the two studied seasons. Twenty four healthy vines without visual nutrient deficiency symptoms were selected. The experiment was designed in a randomized complete block design with three replicates per treatment, one vine each, contained eight treatments as follows:

1- Spraying Yeast at $(10 \mathrm{~g} / \mathrm{L})$.

2- Spraying algae extract at (1 $\mathrm{g} / \mathrm{L})$.

3- Spraying fish oil at (1 $\mathrm{mL} / \mathrm{L}$ ).

4- Spraying yeast $(5 \mathrm{~g} / \mathrm{L})+\mathrm{Al}-$ gae extract $(0.5 \mathrm{~g} / \mathrm{L})$.

5- Spraying yeast $(5 \mathrm{~g} / \mathrm{L})+$ Fish oil $(0.5 \mathrm{~mL} / \mathrm{L})$.

6- Spraying algae extract $(0.5$ $\mathrm{g} / \mathrm{L})+$ Fish oil $(0.5 \mathrm{~mL} / \mathrm{L})$

7- Spraying yeast extract (5 $\mathrm{g} / \mathrm{L})+$ Algae extract $(0.5 \mathrm{~g} / \mathrm{L})+$ Fish oil $(0.5 \mathrm{~mL} / \mathrm{L})$. ter).

8- Control (spraying with wa-

Spraying yeast and algae as well as fish oil solution were prepared by dissolving the assigned amounts in the required water.

All vines were sprayed twice at full bloom and after fruit set until the run-off point. Triton $\mathrm{B}$ at $0.1 \%$ as a wetting agent was used.

The following parameters were measured for both seasons:

ters:

1- Vegetative growth parame-

a- Average leaf area $\left(\mathrm{cm}^{2}\right)$ was estimated by weighing ten mature leaves/vine and weighing 40 sections of $1 \mathrm{~cm}^{2}$ (4 sec. of $1 \mathrm{~cm}^{2} /$ leaf), then the leaf area $\left(\mathrm{cm}^{2}\right)$ was estimated according to the equation:

Leaves weight $(\mathrm{g})$ x Sections area $\left(\mathrm{cm}^{2}\right)$

Sectioins weight (g)

b- Weight of pruning wood of one years old was calculated immediately after pruning (January, 15) and was expressed as $\mathrm{g} /$ vine.

c- Nutritional status: Percentages of $\mathrm{N}, \mathrm{P}$ and $\mathrm{K}$ were determined according to the standard methods outlined by Wilde et al. (1985).

\section{2- Yield components:}

The number of clusters per vine was recorded and the total yield $(\mathrm{kg})$ per vine determined.

3- Cluster and berry characteristic:

At harvesting, two clusters per vine were taken at random and the following characteristics were measured: (cm).

a- Cluster weight (g) and length

b- Weight of 25 berries (g).

c- Number of berries/cluster.

d- Cluster compactness coefficient, according to Winkler et al. (1974).

e- Berry quality including reducing sugar $\%$, total soluble solids (TSS\%) and total acidity (TA\%) (expressed as mg tartaric acid per $100 \mathrm{ml}$ juice), according to A.O.A.C. (1985), as well as total anthocyanin according to Marrkham (1982).

\section{Statistical analysis}

All obtained data were tabulated and statistically analysed according to Gomez and Gomez (1984) and Snedecor and Cochtran (1990) means were compared using the L.S.D. values at $5 \%$ level of the probability. 


\section{Results}

\section{1- Growth characteristics:}

Table (2) exhibits the effect of spraying yeast algae and fish oil on some growth characteristics of Ruby Seedless grapevines in 2015 and 2016 seasons. It is obvious from the data that the results took similar trend during the two studied seasons. Data proved that all treatments had significant increment on the leaf area and weight of pruning wood as well as $\mathrm{N}$, $\mathrm{P}$ and $\mathrm{K} \%$ in leaves compared to untreated vines. Combined applications of these natural materials were significantly superior than using each one in this respect. No significant differences were found due to double form spraying or triple ones. The maximum values were recorded on vines that were sprayed with yeast combined with algae plus fish oil (1043.5 g, $158.7 \mathrm{~cm}^{2}, 2.19 \%, 0.53 \%$ and $1.94 \%$ as an av. two studied seasons for pruning wood weight, leaf area and $\mathrm{N}, \mathrm{P} \& \mathrm{~K}$ percentage in the leaves, respectively. On the other hand, the minimum values of these traits were recorded on the unsprayed vines $(902 \mathrm{~g}, 143.4 \mathrm{~cm}, 1.65 \%$, $0.38 \% \& 1.45 \%$ as an av. the two studied seasons), respectively.

Hence, the increment percentage of pruning wood weight $(15.69 \%)$, leaf area $(10.67 \%), \mathrm{N} \%$ (32.72\%), $\mathrm{P} \%$ (39.47\%) and $\mathrm{K} \%$ $(33.80 \%$ as an av. two studied seasons) due to triple form spraying compared to unsprayed ones. Thus, it could be concluded that spraying either algae or fish oil in a single form as well as any double form or triple form (yeast, algae plus fish oil) improve the vigour and nutrient status of vine.

\section{2- Yield and cluster traits:}

The data presented in Tables (3 $\& 4)$ showed that the number of clusters per vine on the first season did not alter with varying the spraying treatments. On the second studied season, all spraying treatments significantly increased the cluster number and consequently yield/vine compared to unsprayed ones (control).

The highest values of cluster number and yield/vine were found on vines that received all materials together. No significant differences were found due to double form spraying or triple ones as well as singly spraying, whatever yeast, algae or fish oil.

The obtained yield was $(13.45$, $12.82,12.98,14.31,14.21,14.02$, 15.03 and $10.46 \mathrm{~kg} / \mathrm{vine}$ as an av. the two studied seasons) due to yeast, algae, fish oil, yeast plus algae, yeast plus fish oil, algae plus fish oil, triple form spraying and unsprayed ones, respectively. Hence, the corresponding increment of yield/vine due to treatment over unsprayed ones attained $(28.56,22.56,24.09,36.81$, $35.85,34.03$ and $43.69 \%$ ), respectively.

In addition the previous data indicated that all spraying treatments significantly increased the cluster weight and cluster length compared to unsprayed ones. On the other hand, oil fish singly or combined with yeast or algae spraying significantly decreased the berries number per cluster, hence they significantly decreased the compactness coefficient of cluster. The heaviest weight (397.00 g av. the two studied seasons) and lowest compactness coefficient $(5.20$ av. the two studied sea- 
sons) was obtained due to fish oil and yeast plus algae spraying (triple form). Contrarly, the lowest weight value (307.95 g) and highest cluster compactness coefficient (6.34) were found on unsprayed vines (control). Hence the corresponding increment weight percentage was $(28.92 \%)$ and decrement cluster compactness coefficient was (17.98\%), respectively.

So, it could be concluded that spraying fish oil plus yeast or algae (double form) or plus yeast and algae (triple form) improve the cluster traits.

\section{3- Berry quality:}

Tables (4 \& 5) showed that all spraying treatments significantly improved the berry quality in terms of increasing berry weight, total soluble solids $\%$, reducing sugars $\%$ and anthocyanin content in berry skin and decreasing titratable acidity \% compared to unsprayed ones. The best results regarding the berry quality was obtained from the vines that sprayed with triple form. No significant differences were obtained due to triple form or double form spraying. The heaviest 25 berry weight was $64.26 \mathrm{~g}$, whereas the lightest ones $49.04 \mathrm{~g}$ as an av. the two studied season was found on vines that were unsprayed. Hence, the increment percentage of berry weight due to the triple form spraying over unsprayed one was (31.04\%). The increase in berry weight and size result an increase in pack able yield, which it is an important target in grapes production.

Table 2. Effect of spraying yeast, algae, fish oil on some growth traits of Ruby Seedless grapevines during 2015 and 2016 seasons.

\begin{tabular}{|c|c|c|c|c|c|c|c|c|c|c|c|c|c|c|c|}
\hline & \multicolumn{3}{|c|}{$\begin{array}{l}\text { Pruning wood } \\
\text { weight (g) }\end{array}$} & \multicolumn{3}{|c|}{ Leaf area $\left(\mathrm{cm}^{2}\right)$} & \multicolumn{3}{|c|}{ N\% } & \multicolumn{3}{|c|}{ P\% } & \multicolumn{3}{|c|}{ K\% } \\
\hline & 2015 & 2016 & Mean & 2015 & 2016 & Mean & 2015 & 2016 & Mean & 2015 & 2016 & Mean & 2015 & 2016 & Mean \\
\hline $\begin{array}{l}\text { 1- Spraying yeast at } \\
(10 \mathrm{~g} / \mathrm{L}) \text {. }\end{array}$ & 968 & 1015 & 991.5 & 147.7 & 152.7 & 150.2 & 1.96 & 2.11 & 2.04 & 0.47 & 0.48 & 0.48 & 1.78 & 1.82 & 1.80 \\
\hline $\begin{array}{l}\text { 2- Spraying algae } \\
\text { extract at }(1 \mathrm{~g} / \mathrm{L}) \text {. }\end{array}$ & 990 & 1042 & 1016.0 & 151.2 & 157.8 & 154.5 & 2.02 & 2.16 & 2.09 & 0.49 & 0.49 & 0.49 & 1.83 & 1.88 & 1.86 \\
\hline $\begin{array}{l}\text { 3- Spraying fish oil } \\
\text { at }(1 \mathrm{~mL} / \mathrm{L}) \text {. }\end{array}$ & 986 & 1045 & 1015.5 & 150.0 & 156.3 & 153.2 & 2.01 & 2.15 & 2.08 & 0.47 & 0.48 & 0.48 & 1.83 & 1.85 & 1.84 \\
\hline $\begin{array}{l}\text { 4- Spraying yeast (5 } \\
\mathrm{g} / \mathrm{L})+ \text { Algae extract } \\
(0.5 \mathrm{~g} / \mathrm{L}) .\end{array}$ & 988 & 1054 & 1021.0 & 154.7 & 159.0 & 156.9 & 2.08 & 2.22 & 2.15 & 0.51 & 0.51 & 0.51 & 1.91 & 1.93 & 1.92 \\
\hline $\begin{array}{l}\text { 5- Spraying yeast }(5 \\
\mathrm{g} / \mathrm{L})+ \text { Fish oil }(0.5 \\
\mathrm{mL} / \mathrm{L})\end{array}$ & 982 & 1038 & 1010.0 & 149.2 & 154.7 & 152.0 & 1.98 & 2.18 & 2.08 & 0.49 & 0.50 & 0.50 & 1.82 & 1.90 & 1.86 \\
\hline $\begin{array}{l}\text { 6- Spraying algae } \\
\text { extract }(0.5 \mathrm{~g} / \mathrm{L})+ \\
\text { Fish oil }(0.5 \mathrm{~mL} / \mathrm{L}) \\
\end{array}$ & 990 & 1035 & 1012.5 & 150.0 & 156.3 & 153.2 & 2.00 & 2.18 & 2.09 & 0.50 & 0.49 & 0.50 & 1.82 & 1.88 & 1.85 \\
\hline $\begin{array}{l}\text { 7- Spraying yeast } \\
\text { extract }(5 \mathrm{~g} / \mathrm{L})+ \\
\text { Algae extract }(0.5 \\
\mathrm{g} / \mathrm{L})+ \text { Fish oil }(0.5 \\
\mathrm{mL} / \mathrm{L}) \text {. }\end{array}$ & 1011 & 1076 & 1043.5 & 156.3 & 161.0 & 158.7 & 2.12 & 2.26 & 2.19 & 0.52 & 0.53 & 0.53 & 1.93 & 1.95 & 1.94 \\
\hline $\begin{array}{l}\text { 8- Control (spraying } \\
\text { with water). }\end{array}$ & 868 & 936 & 902.0 & 140.3 & 146.5 & 143.4 & 1.58 & 1.71 & 1.65 & 0.38 & 0.37 & 0.38 & 1.43 & 1.47 & 1.45 \\
\hline LSD at 5\% & 33.16 & 36.38 & & 6.32 & 7.18 & & 0.12 & 0.14 & & 0.06 & 0.05 & & 0.10 & 0.12 & \\
\hline
\end{tabular}


Table 3. Effect of spraying yeast, algae, fish oil on number of cluster, cluster weight and yield/vine of Ruby Seedless grapevines during 2015 and 2016 seasons.

\begin{tabular}{|c|c|c|c|c|c|c|c|c|c|}
\hline & \multicolumn{3}{|c|}{ Number of cluster } & \multicolumn{3}{|c|}{ Cluster weight (g) } & \multicolumn{3}{|c|}{ Yield/vine (kg) } \\
\hline & 2015 & 2016 & Mean & 2015 & 2016 & Mean & 2015 & 2016 & Mean \\
\hline 1- Spraying yeast at $(10 \mathrm{~g} / \mathrm{L})$. & 33.67 & 38.50 & 36.09 & 364.33 & 393.41 & 378.87 & 12.31 & 14.58 & 13.45 \\
\hline ract at $(1 \mathrm{~g} / \mathrm{L})$. & 32.50 & 39.30 & 35.90 & 352.00 & 376.80 & 364.40 & 11.30 & 14.33 & 12.82 \\
\hline 3- Sp & & & & 339.00 & & & 11.85 & 14.11 & \\
\hline st $(5 \mathrm{~g} / \mathrm{L})+$ Algae & 34.80 & 40.50 & 37.65 & $\mid 378.60$ & 394.70 & 386.65 & 12.96 & 15.65 & 14.31 \\
\hline t $(5 \mathrm{~g} / \mathrm{L})+$ Fish oil & 34.62 & 39.65 & 37.15 & 372.33 & 393.35 & 382.84 & 12.91 & 15.51 & 14.21 \\
\hline $\mathrm{t}(0.5 \mathrm{~g} / \mathrm{L})+$ & 35.10 & 41.00 & 38.05 & 366.40 & 391.50 & 378.95 & 12.66 & 15.38 & 14.02 \\
\hline $\begin{array}{l}\text { 7- Spraying yeast extract }(5 \mathrm{~g} / \mathrm{L})+ \\
\text { Algae extract }(0.5 \mathrm{~g} / \mathrm{L})+\text { Fish oil } \\
(0.5 \mathrm{~mL} / \mathrm{L}) \text {. }\end{array}$ & 34.65 & 41.60 & 38.13 & 392.70 & 401.30 & 397.00 & 13.57 & 16.48 & 15.03 \\
\hline & & 34.80 & 33.74 & 297.60 & & 307.95 & .83 & 11.08 & 10.4 \\
\hline LSD at $5 \%$ & N.S. & 2.38 & & \begin{tabular}{|l|}
15.94 \\
\end{tabular} & 21.18 & & 0.96 & 1.18 & \\
\hline
\end{tabular}

Table 4. Effect of spraying yeast, algae, fish oil on some cluster traits and 25 berry weight (g) of Ruby Seedless grapes during 2015 and 2016 seasons.

\begin{tabular}{|c|c|c|c|c|c|c|c|c|c|c|c|c|}
\hline & \multicolumn{3}{|c|}{$\begin{array}{c}\text { Cluster length } \\
(\mathrm{cm})\end{array}$} & \multicolumn{3}{|c|}{$\begin{array}{c}\text { Number of ber- } \\
\text { ries/cluster }\end{array}$} & \multicolumn{3}{|c|}{$\begin{array}{c}\text { Cluster compact- } \\
\text { ness coefficient }\end{array}$} & \multicolumn{3}{|c|}{$\begin{array}{l}\text { Weight of } 25 \text { ber- } \\
\text { ries }(\mathrm{g})\end{array}$} \\
\hline & 2015 & 2016 & Mean & 2015 & 2016 & Mean & 2015 & 2016 & Mean & 2015 & 2016 & Mean \\
\hline $\begin{array}{l}\text { 1- Spraying yeast at } \\
(10 \mathrm{~g} / \mathrm{L}) \text {. }\end{array}$ & 25.66 & 26.15 & 25.91 & 153.9 & 155.6 & 154.75 & 6.00 & 5.96 & 5.98 & 55.31 & 57.60 & 56.46 \\
\hline $\begin{array}{l}\text { 2- Spraying algae } \\
\text { extract at }(1 \mathrm{~g} / \mathrm{L}) \text {. }\end{array}$ & 26.14 & 27.10 & 26.62 & 155.4 & 157.2 & 156.30 & 5.95 & 5.79 & 5.87 & 53.30 & 54.93 & 54.12 \\
\hline $\begin{array}{l}\text { 3- Spraying fish oil } \\
\text { at }(1 \mathrm{~mL} / \mathrm{L}) \text {. }\end{array}$ & 24.81 & 25.98 & 25.39 & 130.2 & 131.4 & 130.80 & 5.24 & 5.10 & 5.17 & 58.11 & 61.35 & 59.73 \\
\hline $\begin{array}{l}\text { 4- Spraying yeast (5 } \\
\mathrm{g} / \mathrm{L})+ \text { Algae extract } \\
(0.5 \mathrm{~g} / \mathrm{L}) \text {. }\end{array}$ & 25.75 & 26.68 & 26.22 & 146.4 & 148.6 & 147.50 & 5.92 & 5.77 & 5.85 & 59.35 & 63.39 & 61.37 \\
\hline $\begin{array}{l}\text { 5- Spraying yeast (5 } \\
\mathrm{g} / \mathrm{L})+ \text { Fish oil }(0.5 \\
\mathrm{mL} / \mathrm{L}) \text {. }\end{array}$ & 25.18 & 26.36 & 25.77 & 132.6 & 136.4 & 134.50 & 5.28 & 5.27 & 5.28 & 62.80 & 65.14 & 63.97 \\
\hline $\begin{array}{l}\text { 6- Spraying algae } \\
\text { extract }(0.5 \mathrm{~g} / \mathrm{L})+ \\
\text { Fish oil }(0.5 \mathrm{~mL} / \mathrm{L})\end{array}$ & 25.31 & 26.41 & 25.86 & 134.1 & 135.8 & 134.95 & 5.29 & 5.20 & 5.25 & 61.94 & 63.85 & 63.39 \\
\hline $\begin{array}{l}7 \text { 7- Spraying yeast } \\
\text { extract }(5 \mathrm{~g} / \mathrm{L})+ \\
\text { Algae extract }(0.5 \\
\mathrm{g} / \mathrm{L})+ \text { Fish oil }(0.5 \\
\mathrm{mL} / \mathrm{L}) \text {. }\end{array}$ & 25.65 & 26.58 & 26.12 & 133.6 & 134.9 & 134.25 & 5.27 & 5.13 & 5.20 & 63.16 & 65.35 & 64.26 \\
\hline $\begin{array}{l}\text { 8- Control (spraying } \\
\text { with water). }\end{array}$ & 22.10 & 22.73 & 22.42 & 139.8 & 144.8 & 141.3 & 6.33 & 6.35 & 6.34 & 49.38 & 50.30 & 49.04 \\
\hline LSD at $5 \%$ & 1.05 & 0.98 & & 5.61 & 6.15 & & 0.22 & 0.31 & & 2.38 & 2.38 & \\
\hline
\end{tabular}


Table 5. Effect of spraying yeast, algae, fish oil on TSS \%, reducing sugar \%, anthocyanin content and titratable acidity \% of Ruby Seedless grapevines during 2015 and 2016 seasons.

\begin{tabular}{|c|c|c|c|c|c|c|c|c|c|c|c|c|}
\hline & \multicolumn{3}{|c|}{ T.S.S. \% } & \multicolumn{3}{|c|}{$\begin{array}{c}\text { Reducing sugar } \\
\%\end{array}$} & \multicolumn{3}{|c|}{$\begin{array}{c}\text { Titratable acidity } \\
\%\end{array}$} & \multicolumn{3}{|c|}{$\begin{array}{l}\text { Anthocyanin } \\
\text { mg/g }\end{array}$} \\
\hline & 2015 & 2016 & Mean & 2015 & 2016 & Mean & 2015 & 2016 & Mean & 2015 & 2016 & Mean \\
\hline 1- Spraying yeast at $(10 \mathrm{~g} / \mathrm{L})$. & 16.50 & 17.60 & 17.05 & 12.79 & 13.46 & 13.13 & 0.32 & 0.31 & 0.32 & 1.58 & 1.56 & 1.57 \\
\hline $\begin{array}{l}\text { 2- Spraying algae extract at (1 } \\
\mathrm{g} / \mathrm{L}) \text {. }\end{array}$ & 16.38 & 17.35 & 16.87 & 12.62 & 13.23 & 12.93 & 0.30 & 0.32 & 0.31 & 1.57 & 1.56 & 1.57 \\
\hline $\begin{array}{l}\text { 3- Spraying fish oil at (1 } \\
\mathrm{mL} / \mathrm{L}) \text {. }\end{array}$ & 17.10 & 17.42 & 17.26 & 13.18 & 13.44 & 13.31 & 0.31 & 0.31 & 0.31 & 1.64 & 1.55 & 1.59 \\
\hline $\begin{array}{l}\text { 4- Spraying yeast }(5 \mathrm{~g} / \mathrm{L})+ \\
\text { Algae extract }(0.5 \mathrm{~g} / \mathrm{L}) .\end{array}$ & 16.72 & 17.25 & 16.99 & 12.92 & 13.48 & 13.20 & 0.31 & 0.32 & 0.31 & 1.60 & 1.56 & 1.58 \\
\hline $\begin{array}{l}\text { 5- Spraying yeast }(5 \mathrm{~g} / \mathrm{L})+ \\
\text { Fish oil }(0.5 \mathrm{~mL} / \mathrm{L}) .\end{array}$ & 17.18 & 17.55 & 17.37 & 13.26 & 13.75 & 13.51 & 0.30 & 0.28 & 0.29 & 1.63 & 1.54 & 1.59 \\
\hline $\begin{array}{l}\text { 6- Spraying algae extract }(0.5 \\
\text { g/L }+ \text { Fish oil }(0.5 \mathrm{~mL} / \mathrm{L})\end{array}$ & 16.83 & 17.29 & 17.06 & 12.69 & 13.38 & 13.04 & 0.31 & 0.32 & 0.31 & 1.58 & 1.53 & 1.56 \\
\hline $\begin{array}{l}\text { 7- Spraying yeast extract (5 } \\
\text { g/L) + Algae extract }(0.5 \\
\text { g/L) + Fish oil }(0.5 \mathrm{~mL} / \mathrm{L})\end{array}$ & 17.50 & 18.00 & 17.75 & 13.35 & 13.50 & 13.43 & 0.30 & 0.29 & 0.29 & 1.67 & 1.63 & 1.65 \\
\hline $\begin{array}{l}\text { 8- Control (spraying with wa- } \\
\text { ter). }\end{array}$ & 15.80 & 16.55 & 16.18 & 12.08 & 12.53 & 12.31 & 0.38 & 0.41 & 0.39 & 1.51 & 1.45 & 1.48 \\
\hline LSD at $5 \%$ & 0.49 & 0.63 & & 0.52 & 0.39 & & 0.03 & 0.04 & & 0.05 & 0.06 & \\
\hline
\end{tabular}

Also, the highest total soluble solids were $17.75 \%$ and anthocyanin contents were $1.65 \mathrm{mg} / \mathrm{g}$ as an av. the two studied seasons. On the contrary, the least values of total soluble solids $(16.18 \%)$ and anthocyanins (1.48 $\mathrm{mg} / \mathrm{g}$ ) were recorded on unsprayed vines (control). Hence, the increment percentage of these traits were $9.70 \%$ and $11.49 \%$ as an av. the two studied seasons, respectively. Also, such spraying treatment induces decrement percentage in titratable acidity (25.64\% as an av. the two studied seasons). From the present results it could be concluded that spraying fish oil, yeast and algae at any double form or triple form improved the growth and nutritional status as well as yield and berry quality of Ruby Seedless grapevines.

\section{Discussion}

Using the bio-fertilizer improves the growth and berry characteristics due to the reliable role of bio-fertilizer on enhancing the water holding capacity, soil structure aggregation, soil organic matter and humid substances may increase the availability of nutrients and reduce soil $\mathrm{pH}$ and salinity (Nijjar, 1985 and Darwish et al., 1995). Moreover, it activites the availability uptake and translocation of most nutrients, that accelerating carbohydrate and protein synthesis and nutrient movement, encouraging cell division and development of meristematic tissues. In addition, it induces resistance of plant to root diseases and controlling vegetative growth of tree, then, improving its productivity (Gaur et al., 1980 and Suba Rao, 1984). The above mentioned results were in accordance with those obtained by Ahmed et al. (1997), El-Mogy et al. (1998), Nomier (2000), Ismaeil et al. (2003), El-Salhy et al. (2006), Mostafa (2008), El-Salhy et al. (2011) and Masoud (2012). They concluded that yeast spraying could improve the growth aspects, yield and berry qual- 
ity. The extract of algae has been reported to induce many positive changes in treated plants such as improved fruiting, increased nutrient uptake, resistance to stress conditions and reduced incidence of fungal and insect attack (Metting et al., 1990). The improving effects of algae extracts were emphasized by Eman, Abdel-Moniem and Abd-Allah (2008), Khan et al. (2012) and Mohamed et al. (2013). They pointed out that the growth and fruiting of different grapevines were positively affected by algae extract spraying. Fish oil has been reported as an efficient bloom thinner (McArthey et al., 2006). The use of fish oil has increased fruit diameter on Golden Delicious (David et al., 2008). Use fish oil combination with Lime sulphur could reduced the germination pollen tube growth and fertilization (Yoder et al., 2009). The promotive effect of fish oil spraying was emphasized by McArthey et al. (2006), David et al. (2008) and Yoder et al. (2009).

\section{Conclusion}

It can be concluded that foliar application of yeast, Algae and fish oil and their combinations have a positive effect on growth and berry quality of grapevines. Hence, it could be recommended that using yeast at 5 $\mathrm{g} / \mathrm{L}$ in combination with algae at 0.5 $\mathrm{cm} / \mathrm{L}$ and fish oil at $0.5 \mathrm{~cm} / \mathrm{L}$ twice at full bloom and after fruit set is important to improve nutritional status of grapevines and produce a high yield with good cluster and berry traits.

\section{References}

Association of Official Agricultural Chemists (A.O.A.C.) (1985): Official Methods of Analysis A.O.A.C. Benjamin Franklin Station, Washington, D.C. M.S.A. pp. 440-512.
Abd El-Migeed, A.A.; A.B. El-Sayed and H.S.A. Hassan (2004): Growth enhancement of olive transplants by broken cells of fresh green algae as soil application. Minufia J. Agric. Res., 29 (3): 723-737.

Abd El-Hamid, Samah, Y.A.E. (2002): Effect of bio-fertilizer on yield and berry quality of grapevines. M.Sc. Thesis, Fac. Agric., Mansoura Univ. Egypt.

Ahmed, F.F.; M.A. Ragab; A.A. Ahmed and A.E.M. Mansour (1997): Improving the efficiency of spraying different nutrients for Red Roomy grapevines (Vitis vinifera L.) by using glycerol and active dry yeast. Egypt. J. Hort. 24 (1): 91-108.

Cassan, L.; I. Jean; J. Lamaze and J.F. Morotgaudry (1992): The effect of the Ascophylum nodosum extract Geomer GA14 on growth of spinach. Bot. Mar. 35: 437-439.

Darwish, O.H.; N. Persaud and P.C. Martens (1995): Effect of long term application of animal manure on physical properties of three soils. Plant and Soil, 175: 289-295.

David I. Berlanga Reyes, Alejandro Romo Chacón, Ángel R. Martínez Campos y Víctor M. Guerrero Prieto (2008): Apple fruit chemical thinning in Chihuahua, Mexico. Rev. Fitotec. Mex. Vol. 31 (3): 243-250.

El-Mogy, M.M.; A.H. Omar and S.G. Aisha (1998): Effect of yeast application on bud fertility, physical, chemical properties, vegetative growth and yield of "Tompson Seedless" grapevine. J. Agric. Sci., Mansoura Univ., 28 (8): 37-58.

El-Salhy, A.M.; H.M. Marzouk and M.M. El-Akkad (2006): Biofertilization and elemental sulphur effects on growth and fruiting of King's Ruby and Roomy grapevines. Egyptian J. of Horti., 33: 2944. 
El-Salhy, A.M.; K.I.A. Amen; A.A.B. Masoud and A.A. Eman Abozeed (2011): Response of Ruby Seedless and Red Roomy grapevines to application of some bio-fertilizers. Assiut J. Agric. Sci., 41 (5): 125142.

Eman, A. Abd El-Moniem and A.S.E. Abd-Allah (2008): Effect of green algae cells extract as foliar spray on vegetative growth, yield and berries quality of superior grapevines. Am. Euras J. Agric. and Envirion. Sci., 4 (4): 427-433.

Ferguson, J.J.; W.T. Auigne; L.H. Allen and K.E. Koch (1987): Growth of $\mathrm{CO}_{2}$ enriched sour orange seedlings treated with gibberellic and cytokinins. Proc. Florida State Hort. Soc. 99: 37-39.

Gaur, A.C, K.P. Qstwal and R.S. Mathur (1980): Save super-phosphate by using phosphor-bacteria. Kheti, 32: 23-35.

Gomez, K.A. and A.A Gomez (1984): Statistical Procedures for Agricultural Research, $2^{\text {nd }}$ Ed. Wily, New York.

Hashem, M.; Y.M. Omran and M. Nashwa Sallam (2008): Efficancy of yeasts in the management of root-knot nematode (Meloidogyne incognita) in flame Seedless grape vines and the consequent on the productivity of the vines. Biocontrol Science and Technology, 18 (4): $357-375$.

Hulme, A.C. (1971): The biochemistry of fruit and their products. Products published by Academic Press, London and New York, Vol. Chap. 2, pp. 65-101.

Idso, S.B.; K.E. Idso, R.L. Garcia; B.A. Kimball and J.K. Hoober (1995): Effect of atmospheric $\mathrm{CO}_{2}$ enrichment and foliar methanol application on net photosynthesis of sour orange trees (Citrus aurantium,
Rutaceae) leaves. Amer. J. of Botany, 82 (1): 26-30.

Ismaeil, Fatten, H.M.; M.T. Wahdan and M. El-Sheikh (2003): Response of Thompson Seedless and Roomy Red grape cultivars to foliar sprays with yeast extract and $\mathrm{GA}_{3}$. J. of Agric. Sci., Mansoura Univ., 28 (8): 6321-6334.

Khan, A.S.; B. Ahmed; M.J. Jaskani; R. Ahmed; A.U. Malik (2012): Foliar application of mixture of amino acid and seaweed (Ascophylum nodosum) extract improve growth and physico-chemical properties of grapes. Int. J. Agric. Biol., 14: 383-388.

Markham, K.P. (1982): Technique of flavonoids identification. Academic Press, London.

Masoud, A.A.B. (2012): Effect of organic and bio nitrogen fertilization on growth, nutrient status and fruiting of Flame Seedless and Ruby Seedless grapevines. Res. J. of Agric. and Biolo. Sci. 8 (2): 8391.

Mc Arthey, S.J.; J. Palmer; S. Davies and S. Seymour (2006): Effects of Lime sulfur and fish oil on pollen tube growth, leaf photosynthesis and fruit set in apple. HortScience, 4: 357-360.

Metting, B.; W.J. Zimmerman; I. Crouch and J. Van Staden (1990): Agronomic uses of seaweed and microalgae In: Akatsuka. I (ed) Introduction to Applied Phycology, pp. 589-628. SPB Academe Publishing, The Hague the Netherlands.

Ministry of Agriculture and Land Reclamation (M.A.L.R., 2014): Bulletin of the Agricultural Statistics Part (2). Summer \& Nili Crops.

Mohamed, A.M.; F.H. Abdel-Aziz, M.A. Mohanmed and A. Gobara (2013): Effect of foliar application of sida compound fertilizer on growth, yield and fruit chemical composi- 
tion of "Early superior" grapevine. J. of Hort. Res., 21 (2): 53-57.

Mostafa, R.A.A. (2008): Effect of bio and organic nitrogen fertilization and elemental sulphur application on growth, yield and fruit quality of Flame seedless grapevines. Assiut J. Agric. Sci., 39 (1): 79-96.

Nijjar, G.S. (1985): Nutrition of fruit trees. Mrs. Usha Raji Kumar, Kilyani, New Delhi, India, 206-234.

Nomier, Saffa A. (2000): Effect of some $\mathrm{GA}_{3}$, vitamins and active dry yeast treatments on vegetative growth, yield and fruit quality of Thompson seedless grapevines. Zagazig J. Agric. Res. 27 (5): 1267-1286, Egypt.

Olmo, H.P., C.S. Hivni, D. Antonacci, L. Pedone, L. Sirotti and G. Zanzi (1981). Estratte all orivista di vitieolturaed. Enotogia diconegliano. Anno. XXXXIV-N.B. Agosto, 315-325.

Osnaya M. and E. Schlösser (1998): Effect of vegetable oils on black spot of roses. Mededelinge Facultiet Landbouww Universiteit Gent 63/3b, 995-998.

Snedecor, G.W. and W.G. Cochran (1990): Statistical Methods $7^{\text {th }}$ Ed. The Iowa State Univ. Press, Ames.
Spinelli, F.; F. Giovanni; N. Massimo; S. Mattia and C. Guglielmo (2009): Perspectives on the use of a seaweed extract to moderate the negative effects of alternate bearing in apple trees. J. Hort. Sci. Biotech., 17 (1): 131-137.

Suba Rao, N.S. (1984): Bio-fertilizers in Agriculture Oxford. IBH Company. New Delhi.

Verna (1990): Role of biotechnology in supplying plant nutrients in the vineties. Fertilizer News 35: 87-97.

Wilde, S.A.; B.B. Gorey; J.G. Layer and J.K. Voigt (1985): Soils and Plant Anaysis for Tree Culture. Oxford and IBH Publishing Co., New Delhi, India, 529-546.

Winkler, A.J.; A.J. Cook; W.M. Kliewer and L.A. Linder (1974). General viticulture. Published by Univ. of California Press, Berkley.

Yoder, K.; Y. Uan; R. Combs; L. Byers; R. Mc Ferson J. and T. Schmidt (2009): Effects of temperature and the combination of liquid Lime sulfur and fish oil on pollen germination, pollen tube growth, and fruit size in apples. HortScience, 44: 1277-1283. 
تأثير رش الخميرة والطحالب وزيت السمك علي نمو و إثمار كروم العنب الروبي اللابذري

علاء عبد الجابر بدوي مسعود ، إيمان عبد الحكيم عبد الله أبوزيد

قسم الفاكهة - كلية الزراعة - جامعة أسيوط

أجريت هذه الدر اسة بمزرعة الفاكهة - كلية الزر اعة - جامعة أسيوط - مــصر خـــله

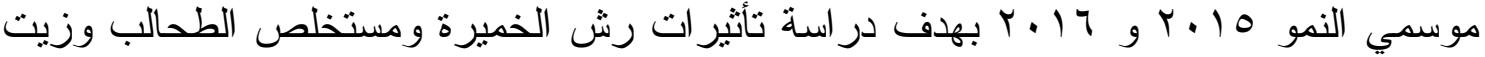

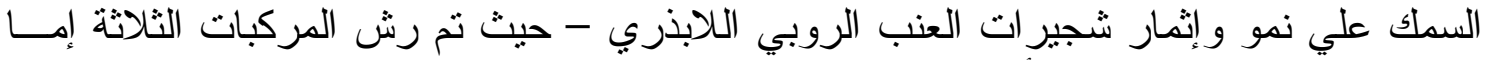

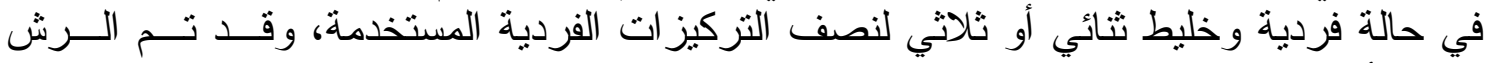
مرنين أثناء اكتمال التزهير هير وبعد العقد. ويمكن تلخيص النتائج كما يلي:

- سبيت جميع معاملات الرش سو اء في صورة فردية أو ثنائية أو ثلاثية زيادة معنوية في وزن

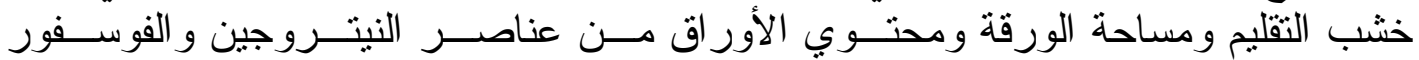

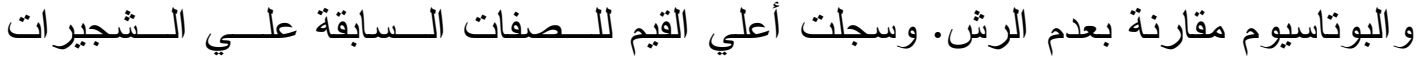

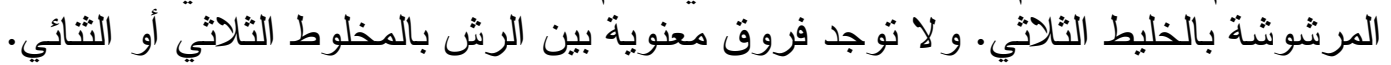

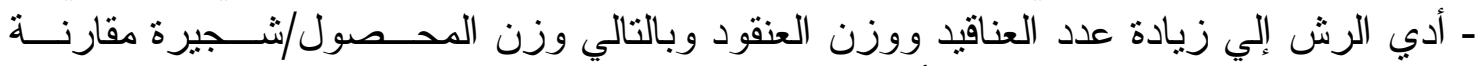

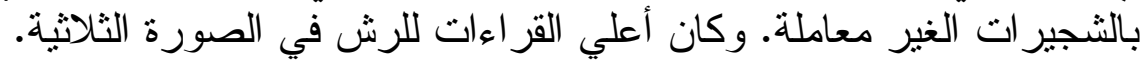

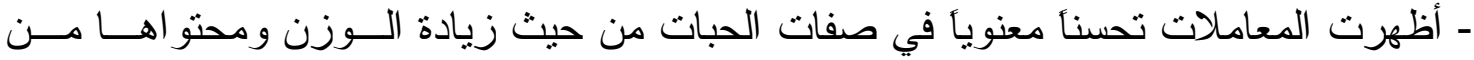

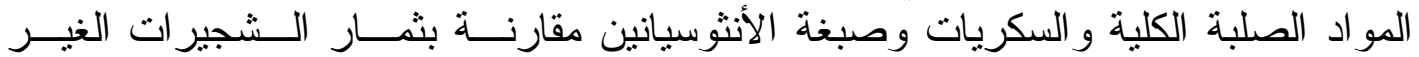
مرشوشة.

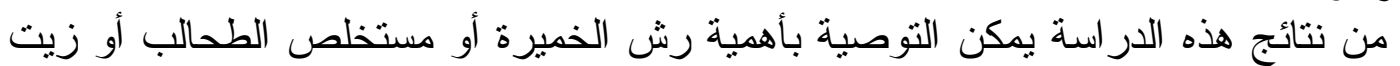

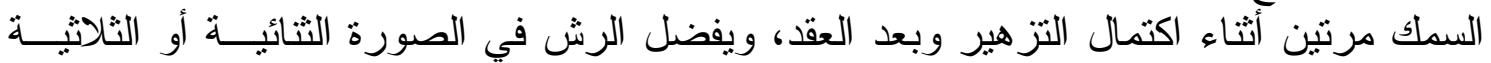

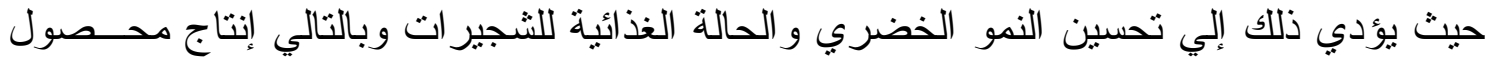
عال ذو خصائص عناقيد وحبات جيدة. 